\title{
New Internet Services and Growth of the Operator's Revenue in Terms of Monopoly
}

\author{
LJILJANA M. MATAVULJ, Regulatory Agency for Electronic Communications \\ and Postal Services, Belgrade \\ ALEKSANDRA M. KOSTIĆ-LJUBISAVLJEVIĆ, University of Belgrade, \\ Professional paper \\ UDC: $338.46: 004.738 .5$ \\ 339.13 \\ DOI: 10.5937/tehnika1801139M
}

Faculty of Transport and Traffic Engineering, Belgrade

\begin{abstract}
This paper begins with the current state of the electronic communications market in general, whose specificity is the existence of so-called a Significant Market Power (SMP) operator, and its ex-ante regulation by national regulatory authorities under predefined rules, that are based on EU legislation. European regulatory framework has changed many times and the number of markets with SMP operator also changed. Special attention has to be put on the existence of Internet market with of dominant wholesale operators. This market records continuous growth in revenues and three groups of participants appear on it: monopolists (one or more), alternative operators and regulator. Taking into account these facts, the paper analyzes the possibilities for simultaneous development of competition and further growth of monopolist's revenues, i.e. how much competition can be useful for the monopolists in the Internet market, either by encouraging himself to introduce new services or by the regulatory activities.
\end{abstract}

Key words: fostering competition, monopolist's revenue, naked Internet, regulated market.

\section{INTRODUCTION}

The electronic communications market features change extremely fast, which occur in the domain of the range of services offered to end users, as well as in the domain of the technologies used for providing these services. Numerous analyses conducted by various institutions: International Telecommunication Union, ITU [1], [2], Body of European Regulatory Authorities, BEREC, and regulatory bodies of the EU member states and EU candidate states, such as Republic of Serbia's regulatory body - the Regulatory Agency for Electronic Communications and Postal Services (RATEL) indicate that this sector has reached the saturation phase and that it is presently functioning as a mature market. Due to the demand for increasingly higher throughput a drop in revenue per gigabyte is occurring across the entire sector, and there are changes in the structure of revenue-generating services,

Authors' address: Ljiljana Matavulj, Regulatory Agency for Electronic Communications, and Postal Services, Belgrade, Palmotićeva 2

e-mail: lj.matavulj@gmail.com

Paper received: 02.02.2018.

Paper accepted: 09.02.2018. which is indicated by the traffic projections for idivividual services.

According to Cisco projections [3], demands for higher throughput will increase several times, because th-roughput will increase several times, because of an increasing number of devices that are in use (smart phones, tablets, laptops, HDTVs, M2M modules,...), and the fact that these same devices are downloading more and more content. The obtained data shows that average traffic per device will increase 5 times in the case of smart phones and M2M modules by 2019. In addition to the decreasing demand for classic telephone services and increased need for Internet access, electronic communications are also a sector where the market competition is based on implementing regulatory measures.

This is not a feature in each sector; therefore competitive incentives are specific in this case. The focus is always on the end user, who needs to have a broad range of possibilities for choosing operators and services, and it is up to the regulator to ensure this if there is a monopoly in the market. The level of success will directly depend on the level of competition at the wholesale market, which is place the regulator should act. Since competition incentives directly lead to new 
entries into the market, as well as mergers and acquisitions, which affect the national economic development in various ways, the role of regulation is even more significant. Regulation in Europe is carried out according precisely defined regulatory framework. It is necessary to ensure greater participation of this sector in national GDP growth, as this is the sector with the highest potential for technological development. Considering the multitude of services that are provided and the fact that there are no universal solutions, a detailed analysis of the real possibilities for inciting competition is necessary in the segments that can lead to greater revenue, the entry of new market participants, and continual growth of the supply and demand of services. This paper is organized as follows. After the introduction, state of the art regarding regulatory framework and competition is presented. Third part of this paper addresses competition at wholesale level of the Internet access market. In fourth part of this paper problem statement is presented and after that part the numerical example and the analysis of obtained results are shown. Concluding remarks are given at the end of this paper.

\section{STATE OF THE ART - REGULATORY FRAMEWORK AND COMPETITION ISSUES}

In the European regulatory regime for electronic communications the main point is the concept of Significant Market Power (SMP). It applies to an operator with dominant position in the telecommunications market, as regards one or more services provide. The existence of a monopolist in a particular market segment provides various opportunities for harming consumers and other market players - potntial competitors of the SMP operator. This problem is particularly characteristic for the telecommunications market which involves operators with a wide range of services that are being rapidly diversified. Determining a fair selling price for the services is a constant challenge in such conditions. In a freely competitive market it is determined under the influence of market forces, by the interaction of supply and demand. In a protected market with a monopoly, the lack of an appropriate level of competition should be offset by the National Regulatory Authority, NRA [4].

Regulation of the electronic communications market in Europe is carried out ex ante (i.e. advance regulation) and is based on a set of European Commission, EC, directives and recommendations and the national legislations of each individual country [5], [6], [7].

For EU candidate countries, the challenges in the regulation of this market are even greater, because it is necessary to incite competition under conditions of monopoly, general market saturation and an insufficiently fast pace of the process of harmonizing the naonal legislation with the changes in the European regulatory framework. If there is an issue pertaining to competition in the retail level, the solution would be sought among the regulation instruments at the wholesale level [8]. The reverse also applies, if new players appear in the retail market, this would imply that the issue of competition has been resolved at this level, and that it is necessary to reassess the regulatory obligations that had previously been imposed on the SMP operator. An innovation is also that in the future the EC intent to regulate services and not the market, because each market in each country has certain specificities that cannot be generalized, and consequently the solutions cannot be provided ex ante. This is confirmed by the analysis conducted by the ITU, where due to the nature of the market, i.e. the networks and services that are provided through them, the regulatory bodies were even recommended to find their own best solutions, ex post, when it was deemed appropriate. Although national regulations in the Republic of Serbia have still not been harmonized with the latest amendments of the EU regulatory framework, there is an identical situation as in the EU markets, in the case of the effects of the market law of supply and demand for services. For this reason, with the aim of the later testing of monopolists' behaviour in the assumed cases of existence of different competitive strategies, revenues data of the Internet market will be taken from the Overview of the telecommunication market and postal services [9]. During year 2015 the total revenues realized in the electronic communications market in Serbia amounted to RSD 1.8 billion and the Internet market accounted for $11.6 \%$ [9]. However, there are still certain issues that prevent the achievement of the full effect of the regulatory measures of NRA generally. Two cases are especially prominent, one at the wholesale level and one at the retail level.

\section{ISSUE OF COMPETITION AT THE WHOLESALE LEVEL OF THE INTERNET ACCESS MARKET}

The broadband Internet access service can be provided in several ways: via Asymmetric Digital Subscriber Line, ADSL, technology with a direct connection to the public fixed operator's network and which allows for constant broadband high-speed Internet access, over copper telephone lines; through the cable operator's cable network; wirelessly, through the mobile network; via leased lines, and access via optic cable. ADSL is defined as a value added service to the telephone service, and not as an independent line, because it utilizes the existing telephone infrastructure [10]. 
Further analysis of the competition issue will focus on broadband Internet access provided by ADSL technology, because this was the service that was being regulated, since there was no possibility for its free substitution with another, neither on the supply nor on the demand side. One SMP operator or SMP's and several Alternative Operators, AOs, were identified in the wholesale market. So far the AOs have been allowed only the ADSL service, which they leased from the SMP operator. The basic precondition for this, i.e. the regulatory obligation that was imposed on the SMP operator, is the publication of the Standard Offer that is offered in this market, to all AOs, under equal terms. It is important to point out that the SMP operator offers these services through its network, while the AO does not have its own access network and offers services through the SMP operator's network, for a set price. The wholesale price of the ADSL connections is defined by the regulatory body, according to a predefined methodology. For most AOs the ADSL connection price is still high, the competition is insufficiently developed, and the penetration level is low. There is growing demand by the AOs from the SMP for higher speed Internet services, but which can be leased independently of the telephone service. One should also add the need of all the operators for creating different service bundles at the retail level. In this sense, the introduction of new service, such as Naked DSL, which can be "packaged" with other AO services, especially with the telephone service if the operator has one, is perceived as the best solution. This fact is confirmed by the examples of many EU member states, and below will refer more to the experience of the two neighbouring countries - Slovenia and Croatia. In both countries there are Naked DSL services and then followed effects of competition, the growth of supply and demand, revenue and penetration. Although the models for price determining were slightly different, but based on costs, the effects were the same - growth in demand for Internet services in retail, growth and greater range of package offered services AO's, total revenue growth in the Internet market and the penetration growth Internet services in general.

Naked DSL actually represents the leasing of a digital broadband subscriber line by the AO, without the obligation to use the public fixed telephone service of the operator providing the leasing service (incumbent). At the same time, we also have to understand the changes on the demand side at the retail level, where the increasingly widespread use of mobile telephones is cause to a drop in interest for fixed telephone lines, which often only represent an additional expense. This is especially prominent among members of the younger population and their households. The offer of an independent broadband Internet access service in
Serbia is almost nonexistent, because it is provided solely in bundles - with public fixed telephony voice service in the case of the SMP operator, or bundled with cable television services in the case of cable operators. The advantages of Naked DSL are: introduction of service without additional expenses; lower prices for users; reliable service (provided via existing telephone cables); free local and national calls for telephone services offered by operators that are users of the SMP operator's Standard Offer. At the same time, this would lead to development of the competition in the wholesale local-tandem broadband access, as well as two retail markets - access to the public telephone network at a fixed location for residential customers and call termination on individual public telephone networks provided at a fixed location. This would primarily reflect on:

- a greater AO stake in providing broadband access services using ADSL technology and telephone services (at the moment all together they have around $5 \%$ of the users of the fixed telephone service);

- the possibility for small operators to start providing bundled services, and therefore "survive" in the current market of the users of this Standard Offer.

- the opening of the possibility for broadband access to be offered retail without the condition that this service be purchased together with telephone sevices and/or media content services.

From the standpoint of the regulator, which is in charge of the state of the entire market, and not of the individual interests of the SMP operators or AOs, the introduction of Naked DSL would inevitably lead to the decrease in the number of users in the SMP operator's network. However, this would be achieved with a smaller loss than if the SMP operator's users were to transfer to the network of another operator. The constant growth of the number of transferred numbers of users in the fixed network is evident from Figure 1, and the consequence of the continued trend of users transferring out of the SMP operator's network to the networks of other operators would certainly left the SMP operator without revenue, while Naked DSL would generate revenue.

The key issue is determining the price of this service, which would allow the operation of the operators that are users of the SMP operator's Standard Offer, and also provide a reasonable profit for the SMP operator to cover the investments that it has had in developing the access network. According to current regulations in the Republic of Serbia, the defined price should be cost-based, with the possibility of applying additional methods - benchmark and Retail Minus 
[11]. Since NRA already has a mechanism for defining prices of regulated services, the only question remaining for the regulator is: what is the optimal time period between the adoption of the decision to introduce the new service into the Standard Offer of the SMP operator and the defining of the price level. Further behaviour by the end users would depend on the price competition of all the market participants and the competition for the best quality of service, which is the purpose and justification for inciting competition in general.

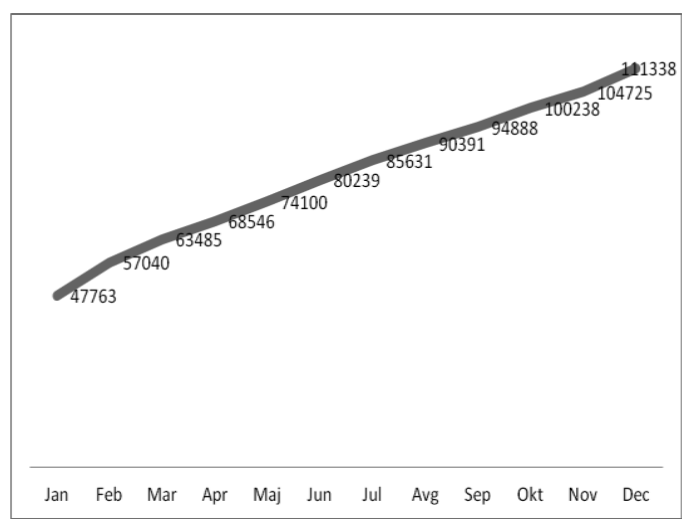

Figure 1 - Ported numbers, by month, 2015 [2]

\section{PROBLEM STATEMENT}

The aim is to provide revenue growth for operators, through the growth of demand for operator services, as well as diversification of the offer, with affordable price from customer's point of view. In the long run, the operator can expect a decline in the price of the service and revenue growth, through increased demand by more number of service users.

These economic laws are the same at both levels: wholesale - where are introduced a new service, and retail level - where are generated the most of the income thanks to a new service on wholesale level. Analyzing the retail market situation in Serbia, with the current margin of $44 \%$ (with VAT), a better choice would be the price calculation Naked DSL by Slovenian model, because it gets a little lower than the current retail price.

This would have a positive impact on all market participants, as it would certainly increased demand, primarily for packages. SMP operator should also have higher incomes, which would be based on the growing number of cheaper services users. A larger number of users would lead to greater market penetration of the Internet, as well as more revenue from these services. Determining the precise percent growth in each of these parameters should be the subject of special research, but only after the introduction of Naked DSL services. For now we have a positive experience of other countries, regardless of their specificity.
Tables 1 and 2 show calculation of possible Naked DSL prices in Serbia, if we apply pricing models used by Slovenia and Croatia with a current margin of SMP in Serbia of 44\% (included VAT on retail level).

Table 1. Possible Naked DSL price in Serbia, based on benchmark of Croatia and Slovenia

\begin{tabular}{|c|c|c|c|c|c|}
\hline \multicolumn{6}{|c|}{$\begin{array}{l}\text { Current wholesale prices in Serbia and possible calculation } \\
\text { of Naked DSL price (in EUR) }\end{array}$} \\
\hline 1 & 2 & 3 & 4 & 5 & 6 \\
\hline $\begin{array}{l}\text { LLU } \\
\text { - full } \\
\text { access }\end{array}$ & $\begin{array}{l}\text { LLU } \\
- \\
\text { shared } \\
\text { access }\end{array}$ & $\begin{array}{l}\text { Digital } \\
\text { access } \\
(2-1)\end{array}$ & $\begin{array}{l}\text { ADSL } \\
\text { access }\end{array}$ & $\begin{array}{l}\text { Naked } \\
\text { DSL in } \\
\text { Serbia - } \\
\text { used } \\
\text { Slovenian } \\
\text { model } \\
(3+4)\end{array}$ & $\begin{array}{l}\text { Naked } \\
\text { DSL in } \\
\text { Serbia - } \\
\text { used } \\
\text { Croatian } \\
\text { model } \\
(1+4)\end{array}$ \\
\hline 5.35 & 1.77 & 3.58 & 4.72 & 8.30 & 10.07 \\
\hline
\end{tabular}

Table 2. ADSL prices in Serbia, without and with Naked DSL (in EUR)

\begin{tabular}{|c|c|c|c|c|c|}
\hline \multicolumn{4}{|c|}{ Without Naked DSL } & \multicolumn{2}{|c|}{ With Naked DSL } \\
\hline $\begin{array}{l}\text { Retail } \\
\text { SMP's } \\
\text { price - } \\
\text { the } \\
\text { main } \\
\text { service }\end{array}$ & \multicolumn{2}{|c|}{$\begin{array}{l}\text { Wholesale } \\
\text { SMP`s prices }\end{array}$} & $\begin{array}{l}\text { Retail } \\
\text { SMP's } \\
\text { price for } \\
\text { "packag } \\
\text { ed" } \\
\text { services }\end{array}$ & \multicolumn{2}{|c|}{$\begin{array}{l}\text { Possibilities of retail } \\
\text { SMP`s prices in Serbia, } \\
\text { depend of model }\end{array}$} \\
\hline 1 & 2 & 3 & 4 & 5 & 6 \\
\hline $\begin{array}{l}\text { Monthl } \\
\text { y fixed } \\
\text { access }\end{array}$ & $\begin{array}{l}\text { ADS } \\
\mathrm{L}\end{array}$ & $\begin{array}{l}\text { Total } \\
\text { price } \\
\text { for } \\
\text { other } \\
\text { AO`s } \\
(1+2)\end{array}$ & $\begin{array}{l}\text { BOX2 } \\
\text { of } \\
\text { services } \\
\text { from } \\
\text { columns } \\
1 \text { and } 2 \text {, } \\
\text { with } \\
\text { margin } \\
44 \%\end{array}$ & $\begin{array}{l}\text { Retail } \\
\text { SMP`s } \\
\text { "packaged } \\
\text { "price by } \\
\text { Slovenian } \\
\text { model }\end{array}$ & $\begin{array}{l}\text { Retail } \\
\text { SMP`s } \\
\text { "packaged } \\
\text { "price by } \\
\text { Croatian } \\
\text { model }\end{array}$ \\
\hline 4.58 & 4.72 & 9.30 & 16.66 & 15.66 & 17.43 \\
\hline
\end{tabular}

Note: All prices in Croatia and Slovenia are based on cost accounting model; wholesale prices were taken from Standard Offer Telekom Serbia [12]; retail price from Telekom's price list for BOX2 package in 2015. In order to explore the possibilities for achieving this goal, we will start from an assumed market situation, in which case we will see clear differences between the option when the competition is encouraged, by introducing (on its own initiative or as a regulatory measure) a new service in the existing bundle of services, and when business policy is not changed, both in the environment with significant market power. On the wholesale Internet market this new service could be the Internet service provided through Naked DSL. The main questions are:

- Could the revenues of the monopolists increase even if it would allow the service to compete - at the wholesale level, but without conditional 
purchase of some other service, such as a fixed connection?

- If such change in the business strategy is not initiated neither the regulator nor the monopolist, is there danger that the market will be shut down?

The Internet service provided through the Naked DSL is selected only as an example in which these assumptions can be compared, using the prices given in Tables 1 and 2. For the purpose of our analysis, let us assume certain telecommunication market, with two competitive large telecom operators (A and B) and several small operators and service providers. Operators A and B have significant market power regarding network infrastructure. The basic characteristics of small operators are technological difference in broadband access provisioning. In our research we observe only one telecom service broadband internet access. We assume that there is no difference between end-users (residential or business). Technological difference between operators and providers is mainly presented in possibility of delivering telecommunication services. Operators $\mathrm{A}$ and $\mathrm{B}$ use copper cables and DSL technologies for providing broadband internet access. Other operators and service providers use mainly HFC (Hybrid Fibber Coax) network and mobile access. Main goal of our research is to analyse how does demand decrease of fixed telephone service, influence operators revenue and can Naked DSL concept make some improvement in revenue. By the term Naked DSL we assume only broadband internet access without fixed telephony service. Namely, since end -users have tendency to use voice services mostly over mobile network, and those who still wants to use fixed telephone for communication can use bundle of services offered by many cable operators which include internet access, TV and fixed telephony, there is reasonable assumption that DSL (with fixed line obligation) is going to be abandoned.

\section{NUMERICAL EXAMPLE AND ANALYSIS OF OBTAINED RESULTS}

We assumed certain telecommunication market with similar properties like Serbian market. We also assumed than, at the starting point of our analysis, both operators have the same number of end-users, which corresponds to the half of current number of end-users on Serbian market. As already mentioned for the general trend in the electronic communications market, the same situation is on the Serbian market - a decrease in fixed telephone service revenues and an increase in Internet revenue, which is shown in Table 3.

It is also relevant that the fixed telephony market has the possibility of numbers portability and end- users are intensively used it in the retail market (Figure 1). It impacts on behaviour of the wholesale operators and changing their income, especially when the replacement of their services is done through a package. Below we will consider different market behaviours in the case of a duopoly.

Table 3. Revenues from fixed telephone services and the Internet in Serbia [9]

\begin{tabular}{|l|l|l|l|l|}
\hline \multirow{2}{*}{ Years } & \multicolumn{2}{|l|}{$\begin{array}{l}\text { Revenue from fixed } \\
\text { telephone services } \\
\text { (milions) }\end{array}$} & \multicolumn{2}{l|}{$\begin{array}{l}\text { Revenue from Internet } \\
\text { (milions) }\end{array}$} \\
\cline { 2 - 5 } & RSD & EUR & RSD & EUR \\
\hline 2011 & 43.800 & 365,00 & 14.910 & 124,25 \\
\hline 2012 & 40.400 & 336,67 & 18.030 & 150,25 \\
\hline 2013 & 37.700 & 314,17 & 19.450 & 162,08 \\
\hline 2014 & 37.600 & 313,33 & 20.020 & 166,83 \\
\hline 2015 & 37.400 & 311,67 & 21.660 & 180,50 \\
\hline
\end{tabular}

This analysis is influenced with the change of the number of end-users due to their rejection of the usage of fixed telephone connection. It is assumed that the operator $A$ provides xDSL access (with the obligation to use the telephone service), while operator $B$ offers Naked DSL. Also, it is assumed that the number of end-users of the operator A and operator B at the beginning of the analysis is the same. We analyse situation in which exists decrease of number of endusers of operator A by $10 \%$.

If the number of xDSL users who have signed contract with the operator $A$ starts to decrease from $45 \%$ to $35 \%$, then there is concern about their new contracts. We assume that end-users will remain their habits about broadband internet access, which implies that they will only change the operator. Depending on current bundle of services offered by operators/providers on observed telecommunication market, those end-users will decide on one of the offered service or bundle of services. According to the data used in our calculation, in the Republic of Serbia there are around $1,600,000$ broadband users of which about $45 \%$ is xDSL users (about 720,000) [9]. It is assumed that out of the total number of users on this type access (xDSL), $70 \%$ represent retail customers, and $30 \%$ use the services through the operators of the wholesale xDSL access services of operators $A$ and $B$. As shown in Table 2, the retail price of the service package if the operator decides to provide Naked DSL access is 15.66 EUR (operator $B$ ), and in case he does not provide Naked DSL access (operator $A$ ) the price is 16.66 EUR.

With the assumed change in the number of users, operator revenues on the retail xDSL access market 
changes, but depend on the assumption which percentage of operator $A$ users goes to the same type of technology of operator $B$. The analysis was conducted for 4 possible Scenarios:

Scenario 1: All users who cancel xDSL contract with the operator $A$ will make Naked DSL contract with the operator $B$; Scenario 2:_Half of all users who cancel xDSL contract with the operator $A$ will make Naked DSL contract with the operator $B$ and others will make new contracts with operator/provider that uses other broadband access technology; Scenario 3:

One third of all users who cancel xDSL contract with the operator $A$ will make Naked DSL contract with the operator $B$ and others will make new contracts with operator/provider that uses other broadband access technology; Scenario 4:-One quarter of all users who cancel xDSL contract with the operator $A$ will make Naked DSL contract with the operator $B$ and others will make new contracts with operator/provider that uses other broadband access technology.

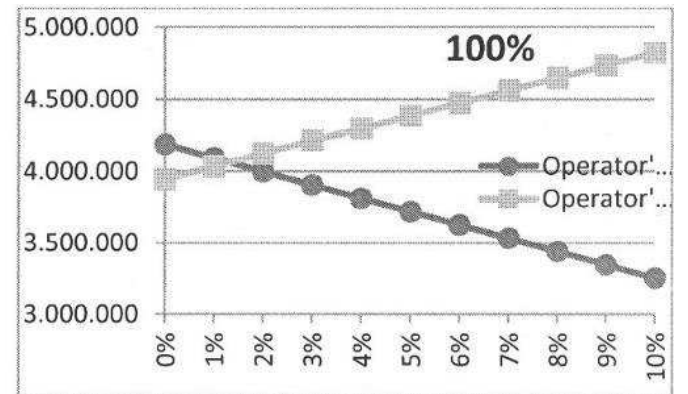

Figure 2 - Revenue of operator A and operator $B$ when Scenario 1 is applied

Figure 2 shows a graphical interpretation operator's $A$ and operator's $B$ revenue in case described in Scenario 1. On the $x$ axis the percentage of number of end-users is shown, and on the $y$ axis the revenue of operator $A$ and operator $B$ expressed in EUR is shown. It can be noticed that the revenue of operator $A$ decreases with decreasing the number of users. Also, at the same time there is an increase in the revenue of operator $B$, but only after a certain percentage $(1 \%)$ of users who have signed a contract with operator $B$.

In Figure 3 is similarly displayed Scenario 2, i.e. the situation when only half of the users who have cancelled the contract with operator $A$ make a new contract with the operator $B$. The second half of the users who have terminated the contract with the operator $A$ signed a contract with one of operators/providers who offer services provisioned by some other broadband technologies.

This market segment is not subject to the analysis presented here. This figure shows that the revenue of the operator $B$ increases after almost $2 \%$ assumed users.

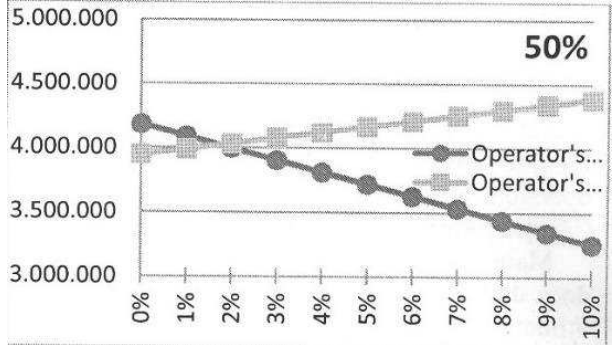

Figure 3 - Revenue of operator A and operator $B$ when Scenario 2 is applied

Figure 4 shows the change of the revenue of the operator $A$ and operator $B$ when Scenario 3 is applied, that is, when only a third of users who have cancelled the contract with the operator $A$ sign a new contract with the operator $B$.

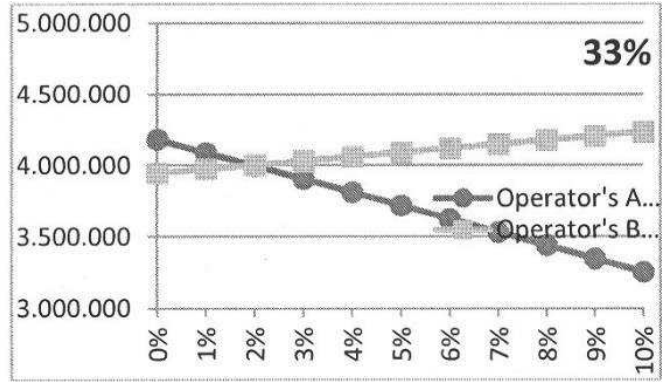

Figure 4 - Revenue of operator $A$ and operator $B$ when Scenario 3 is applied

Similarly, Figure 5 shows the change of revenues of operator $A$ and operator $B$ under Scenario 4, according to which only a quarter of users who cancel DSL contract with the operator make a Naked DSL contract with the operator $B$.

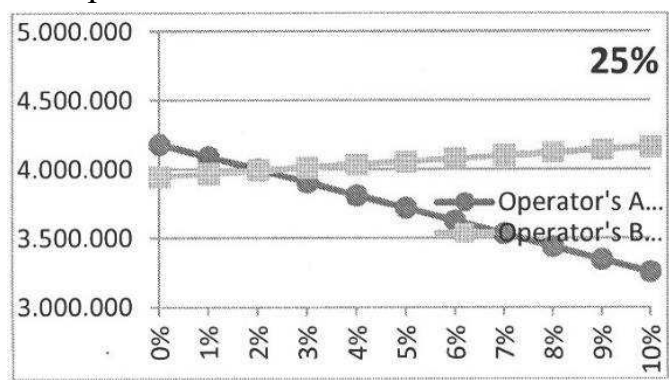

Figure 5 - Revenue of operator A and operator $B$ when Scenario 4 is applied

On all figures from 2 to 5 there is a drop in operator $A$ revenue, and increase in operator $B$ revenue over a given period of time and in terms of transferring the number of users from one operator to another. Obviously, the number of retail customers of operator $A$ is decreasing and the number of operator $B$ users increases depending on the percentage of operator $A$ users who pass to the same type of operator $B$ technology. Although operator $B$ has a lower retail service price, it will generate higher revenues due to nature of services that allow greater flexibility in creating a service package which will attract more users. Operator $A$, 
which does not introduce a Naked DSL service, has only an initial advantage in revenue, due to higher service prices and the initial number of users. The end result in the longer term will be more affected by the number of users of the service, than the price at which it is provided.

\section{CONCLUSION}

In the broadband Internet market, in the assumed situation of the existence of some form of monopoly (in the our work it is a duopoly) and the presence of smaller alternative operators in that market, it was noticed that the monopolists will have a growth in retail sales in the long run if they introduce a Naked DSL on the wholesale level.

This will not affect the loss of the competitive power of the monopolist in retail, in the sense that it will lose customers who will permanently pass on to its competitors. This service will not always be offered by itself, but within different packages that will only diversify the range of services that generate revenues of monopolists and alternative operators.

Users under these circumstances can go on several occasions with another operator, but also to return to the previous one. In a wider context, the Internet market as a whole will develop (the volume of the economy will be achieved), with the increased demand for services of higher quality and a wider range.

The competition game would be transferred during time from the basic - price with a weaker offer, to the higher level - with a focus on the quality of services in a diversified offer. This would gradually move from a classical monopoly to a market that gravitates towards effective competition.

The paper proved that it was possible to achieve the goal that served as a precondition, that is, in the fixed telephony market whose revenues are decreasing, a possible change trend in the direction of revenue growth, the introduction of the Naked DSL service. Regarding to the characteristics of this market, this can be done only in two ways: either by the intervention of a regulator when it is judged to be appropriate in a specific country, or the initiative of the monopolists themselves, when it assesses that this business strategy will be profitable in the long run. Then further focus should be shifted to the quality of services and pricing policies that would develop within selected business strategy. The role of the NRA in terms of a monopoly is to create such conditions that will increase competition.

This paper shows that the introduction of new services by the monopolists can simultaneously achieve objectives of both NRA (fostering competition) and monopolists (revenue growth). This implies that the regulator and the operator together should recognize this opportunity and retain working on improving the electronic communications market, which will lead to greater customer satisfaction services

\section{ACKNOWLEDGEMENT}

This paper is part of the research in project TR32025 of Ministry of education, science and technological development of Republic of Serbia.

\section{REFERENCES}

[1] Broadband: A Platform for progress, A Report by the broadband commission for digital development, 30 36, Geneva, ITU and UNESCO, 2011.

[2] Trends in telecommunication reform: Special edition, fourth-generation regulation: driving digital communications ahead, Geneva, ITU. http://www.itu.int/pub/D-PREF-TTR.15-2014, 2014.

[3] Cisco Visual Networking Index: Forecast and Methodology, 2014-2019, White Paper, 2015.

[4] Matavulj Lj, Milićević V, Primena troškovnog modela u kontroli cena SMP operatora u Srbiji. Zbornik radova (na CD) sa XVI telekomunikacionog foruma - TELFOR 2008. str. 9-12, Beograd, 2008.

[5] European Commission, Commission Guidelines (2002/C 165/03) on market analysis and the assessment of significant market power under the Community regulatory framework for electronic communications networks and services. Official Journal [C C165/6], 2002.

[6] European Commission. Commission recommendation 2003/311/EC on relevant product and service markets within the electronic communications sector susceptible to ex ante regulation in accordance with Directive 2002/21/EC. Official Journal [L 114/45], 2003.

[7] European Commission, Commission recommendation 2007/879/EC of 17 December 2007 on relevant product and service markets within the electronic communications sector susceptible to ex ante regulation in accordance with Directive 2002/21/EC. Offcial Journal [L344/65], 2007.

[8] Explanatory note accompanying the document Commission Recommendation on relevant product and service markets within the electronic communcations sector susceptible to ex ante regulation" in accordance with Directive 2002/21/EC (SWD (2014) 298).

[9] Overview of Telecommunications and Postal Services Market in the Republic of Serbia in 2015. RATEL, Beograd, 2016. 
[10]European Regulators Group, ERG, Bitstream Access: ERG Common Position on wholesale bitstream access. ERG (03), 2014.

[11]Kostić-Ljubisavljević A. at all. Application of the Retail-Minus Concept on Price Regulation in ceedings of the 11th International Conference on Teleco- mmunications in Modern Satellite, Cable and Broadcasting Services TELSIKS 2013. Pp. 133-136, , Niš, 16-19 October 2013

[12]http://www.ratel.rs/upload/documents/Standardne_p onude/Telekom\%20Srbija\%20-\%20usluge\%20sirokopojasnog\%20pristupa $\% 20 \mathrm{u} \% 20$ veleprodaji $\% 201$ 9.08.2015..pdf

\section{REZIME}

\section{NOVI INTERNET SERVISI I PORAST PRIHODA OPERATORA U USLOVIMA MONOPOLA}

Ovaj rad počine prikazom trenutnog stanja na tržištu elektronskih komunikacija, čija je jedna od specifičnosti postojanje takozvanog operatora sa značajnim udelom u tržištu (Significant Market Power, SMP) kao i ex-ante regulativa koju sprovodi nacionalano regulatorno telo po unapred definisanim pravilima baziranim na EU legislativi. Evropski regulatorni okvir se menjao višse puta, kao i broj tržišta koje karakteriše postojanje SMP operatora. Posebna pažnja se mora posvetiti postojanju Internet tržišta sa dominantnim operatorima na veleprodajnom nivou. Ovo tržište karakteriše kontinuirani rast prihoda kao i postojanje tri grupe učesnika na tržištu: monopoliste (jednog ili više), alternativnih operatora $i$ regulatora. Imajući na umu ove činjenice, u ovom radu je izvršena analiza mogućnosti simultanog razvoja konkurencije $i$ daljeg rasta prihoda monopoliste. Drugim rečima, razmatra se koliko konkurencija može biti korisna za monopolistu na Internet tržištu da li kroz podsticanje za uvođenje novih servisa ili regulatornim aktivnostima.

Ključne reči: podsticanje konkurencije, prihod monopliste, Internet, regulisano tržište 